POLIIICAL ECONOMY RESEARCH INSIITUTE

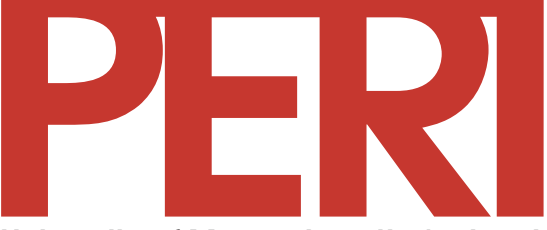

University of Massachusetts Amherst

\title{
Informalization, Economic Growth and the Challenge of Creating Viable Labor Standards in Developing Countries
}

\author{
James Heintz \\ Robert Pollin
}

2003

10th floor Thompson Hall University of Massachusetts Amherst, MA, 01003-7510 Telephone: (413) 545-6355 Facsimile: (413) 545-2921

Email:peri@econs.umass.edu Website:

http://www.umass.edu/peri/

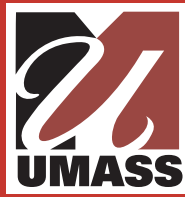




\title{
Informalization, Economic Growth and the Challenge of Creating Viable Labor Standards in Developing Countries
}

\author{
By \\ James Heintz \\ Political Economy Research Institute (PERI) \\ University of Massachusetts-Amherst \\ Amherst, MA 01003-7510 \\ jheintz@econs.umass.edu \\ and \\ Robert Pollin \\ Department of Economics and \\ Political Economy Research Institute (PERI) \\ University of Massachusetts-Amherst \\ Amherst, MA 01003-7510 \\ pollin@econs.umass.edu
}

June 2003

We wish to thank participants at the at October 2002 Cornell University conference, "Rethinking Labor Market Informalization: Precarious Jobs, Poverty, and Social Protection," and at the January 2003 ASSA/IAFFE session "Trade Openness, Labor Market Informalization and Women's Wages: An International Perspective." We would also like to thank Jacques Charmes for the use of his estimates of the extent of informalization and to Gerald Epstein for helpful suggestions. Of course, all errors remain our own. 


\title{
Informalization, Economic Growth and the Challenge of Creating Viable Labor Standards in Developing Countries
}

\author{
By James Heintz and Robert Pollin, University of Massachusetts-Amherst
}

June 2003

\begin{abstract}
Over recent decades, there has been the substantial rise in the proportion of people engaged in what is termed informal employment, generating a broad trend toward "informalization" of labor market conditions in developing countries, even when economic growth is proceeding. We consider the relationship between the rise of informalization and the corresponding ascendancy of neoliberal policies in developing countries, focusing in particular on how the decline in average per capita GDP growth associated with neoliberalism has fostered informalization. We then explore policy measures for raising the proportion of decent jobs with core social protections in developing countries - which means, as we argue, reversing the process of informalization. We examine policy measures in two areas: raising the rate of economic growth and improving the regulation of labor markets.
\end{abstract}

JEL Classifications: O11, 017, J8 
Over recent decades, conditions for working people in developing countries have undergone a major transformation. This has been the substantial rise in the proportion of people engaged in what is termed "informal" employment, generating a broad trend toward "informalization" of labor market conditions in developing countries. Current estimates suggest that informal employment comprises about one-half to three-quarters of non-agricultural employment in developing countries (ILO 2002b). Moreover, and perhaps even more significantly, these proportions appear to be rising even when economic growth is proceeding in developing countries, contrary to what a previous generation of researchers and policymakers had anticipated (ILO 2002a, Benería 2001, Charmes 2000, Castells and Portes 1989).

Informal forms of employment include, for example, agricultural day laborers, urban street vendors, paid domestic work, or at-home producers of clothing or other manufactured goods. A high proportion of informal workers are self-employed. In most countries, women are disproportionately employed in such informal jobs (ILO 2002a). For the most part, the income workers receive from informal employment in developing countries is very low, often consigning these workers and their families to a poverty-level standard of living, and sometimes to severe poverty (see, for example, ILO 2002a, Unni 2001). Informal jobs also, for the most part, fall outside the sphere of government's supervision of labor markets. That is, informal workers do not operate with the types of legal protections concerning working hours, health and safety or with the types of mandated benefits that would normally be a feature of "formal" employment opportunities in large, ongoing private sector firms or the public sector.

The notion of a distinct informal economy-incorporating more casual, unregulated work arrangements and low wages - has long been a feature of the literature in development economics, and the term "informal sector" itself was introduced in an International Labor Organization publication in 1972 (ILO 1972). But what has become increasingly clear since the early 1970 s is that informal forms of employment are not confined to any single distinct sector of the economy in the sense of a specific industry group or economic activity. Indeed, informal forms of employment span across traditional sectoral categories. Thus, as the most recent comprehensive ILO examination of the question explains, "the term 'informal economy' has come to be widely used instead to encompass the expanding and increasingly diverse group of workers and enterprises in both rural and urban areas operating informally (2002a, p. 2)." Our discussion endorses this more recent understanding of the phenomenon, and thus refers to distinctions between formal and informal forms of employment - and the process of informalization as reflecting the increased prevalence of informal jobs as a share of total employment - as opposed to clearly demarcated formal and informal sectors.

Informal work arrangements are able to flourish when workers have few alternative economic opportunities - that is, weak fallback positions in bargaining situations with employers. Considering only formal employment situations, the wage at which workers are willing to accept jobs will depend in large part on the other job opportunities available to them. As such, informalization will also place downward pressure on wages and working conditions in formal jobs as well. Thus, the process of informalization proceeds in part through a vicious cycle: a relatively high proportion of informal jobs makes it increasingly difficult for workers to bargain for decent wages, working conditions and social protections, so that what had once been formal jobs become increasingly informalized over time.

There are numerous parallels between the process of informalization and more general concerns over worsening employment conditions and the growing prevalence of labor abuses. For example, anti-sweatshop activism in the countries of the global North in recent years reflects a heightened awareness over questions of international labor standards as they pertain to 
manufacturing and industrial production. Similarly, the question of child labor has assumed a greater urgency in international organizations such as the ILO and UNICEF. In many cases, the process of informalization is directly linked to these concerns over human rights violations, downward pressures on poverty-level wages, or a general erosion of working conditions. Sweatshops and factories using child labor often must operate informally since government regulations frequently prohibit many of the most common abuses.

This paper is concerned with considering ways of improving labor conditions in developing countries through raising the proportion of decent jobs with core social protectionsthat is, through reversing the process of informalization. As we will discuss, two basic policy interventions exist for improving labor conditions in developing countries-increasing the rate of economic growth; and improving the regulation of labor markets. We will argue that both types of measures are needed in developing countries to reverse the process of informalization. But what is the relative importance of growth versus the regulatory regime for improving labor conditions? A long-held view was that informal forms of employment would gradually disappear as a consequence of a higher level of GDP alone. However, as noted above and as we will examine in some detail below, this relationship appears to have not held during the past 20 years during which time a commitment to neoliberalism has dominated economic policy throughout the developing world. This means that, in order to reverse the trend toward informalization of employment in developing countries, we must give increased attention to improving labor standards and social protections as compliments to - though certainly not substitutes forpolicies that can accelerate economic growth.

In the next section of the paper, we draw on the existing literature to establish more fully our own understanding of the terms "informal employment" and "informalization" In section 3, we then consider the existing literature on the relationship between economic growth, labor regulations and informalization. We also present two competing explanations for the rise of informalization - what we term overregulation-centered and a neoliberalism-centered explanations. In section 4, we then present our empirical findings on the relationship between economic growth and informalization. We draw here on the two major data sources available for this purpose - the data base developed by the International Labor Organization office in Lima, Peru, and recently up-dated estimates developed by Professor Jacques Charmes of the University of Versailles. ${ }^{1}$ Drawing from this evidence, in section 5 we then present a two-pronged approach to reversing the process of informalization, including policies to both raise the rate of economic growth and also explicitly improve working conditions. We conclude with a brief overview of our main empirical findings and policy perspectives.

\section{Informalization and Labor Standards}

Most scholars of the informal economy define it as the set of remunerative economic activities that exist outside of a formal system of state regulation. Often, activities which involve trade in illicit or criminal goods and services are treated separately and therefore are not included in many working definitions. Similarly, unpaid reproductive labor performed in the household is also excluded. We work with these basic definitional distinctions in our discussion here.

In the early literature, the informal economy was often treated as single, undifferentiated amalgam of subsistence activities. However, recent research has challenged this image of informal activities. Substantial segmentation and a wide range of class distinctions are evident

1 Jacques Charmes generously provided us with the up-dated (2003) estimates used in this paper. For a discussion of earlier estimates using the same methodology, see Charmes (2000). 
within the informal economy, as is a plurality of relationships with the formal economy, a situation which has forced a rethinking of approaches that assign a unified, invariable role to informal activities (Tokman 1989, Gerry 1987, Nattrass 1987, Hart 1973). Some types of informal employment, especially self-employment, provide remuneration well above what wage workers at the low-end of the pay scale receive in formal employment. For example, research in the Dominican Republic revealed that mobile vendors of fruits and vegetables, called lechugueros, would not leave their current occupation for an entry-level formal job because they earn a monthly income substantially above the legal minimum wage (Murphy 1990). Clearly, such situations emerge in the Dominican Republic and elsewhere not primarily because informal employment opportunities are highly desirable, but rather because the formal jobs are highly undesirable. Nevertheless, under most circumstances, formal employment would be preferable to informal work. Thus, average incomes earned through informal activities fall significantly below average incomes earned in similar types of formal employment (ILO 2002a, Unni 2001).

It is important to recognize that, in most economies, women account for the majority of informal workers. Therefore, interventions that affect the level of employment, working conditions, or earnings in the informal economy will have a gender-specific impact. These effects are not limited to the direct effect on informal workers. They also have implications for gender dynamics more broadly - for example, access to money income can determine women's relative bargaining power in the household (Braunstein 2002, Sen 1990, Roldan 1988, Joekes 1987). Similarly, women frequently face different constraints to labor force participation than do men. These constraints, which vary between informal and formal sector opportunities, affect women's access to different forms of paid employment (Balakrishnan 2002). ${ }^{2}$

Early conceptualizations of what eventually was termed the informal sector viewed it consisting of a collection of subsistence activities for individuals excluded from formal employment in labor surplus economies (see, for example, Lewis 1954). The informal sector, therefore, was defined as a residual category, akin to unemployment. In early Marxian analysis, the informal sector represented a collection of pre-capitalist activities that provided both a supply of inexpensive wage-goods and a reserve army of labor from which capitalists could draw as the process of accumulation proceeded (Gerry 1987). Similarly, in many neoclassical models, the inclusion of the informal sector allowed the assumption of full-employment - those without formal sector jobs remained employed, they simply worked informally. Therefore, migrants moving into urban settings who face rationing in the formal labor market would be absorbed into the unregulated informal sector in which incomes or wages adjust to clear the market (see, for example, Hemmer and Mannel 1989).

However, viewing informal employment as simply a residual category fails to recognize that these activities often constitute an important link in a more extensive chain of commodity production and distribution. Therefore, the informal economy's connection to the formal economy goes beyond the typical characterizations of a supplier of cheap wage goods, a direct competitor in overlapping product markets, or a repository for surplus labor. Moreover, many informal activities are not automatically open to anyone who cannot find formal employment. Social networks and a minimum endowment of economic resources can be critical to sustain even

2 Responsibility for unpaid labor, concern over the quality of care, and patriarchal norms can constitute constraints to women's access to formal employment. For example, Sathar and Kazi (1989) found that Pakistani households in which women worked in more formal factory settings had a higher incidence of child mortality than households in which women were engaged in paid home-base production - an outcome that could influence formal labor force participation. 
a subsistence level of activity in the informal economy (Pahl 1985, Meagher 1995, Hart 1973). ${ }^{3}$ Those without these minimal resources are unable to operate in the informal economy. This means that open unemployment - experienced by those without the minimal entry requirements for the informal economy - can co-exist with a expanding informal economy. ${ }^{4}$ All of this suggests that the relationship between informalization and economic growth is likely to be contingent on a range of additional social forces.

\section{Economic growth and informalization}

Does the relative size of informal employment expand or contract with economic growth? Addressing this question is central to an understanding of the connections between informalization and economic development. Early work in the history of industrialization and the emergence of the factory system saw the informal sector as a vestige from a previous era (Dangler 2000). That is, capitalist economic development meant the "formalization" of economic activity, in which formal wage labor relationships replaced alternative, often less formal, arrangements (e.g. petty commodity production, the putting out system, or home-based work).

More recently, the assumption of a universal negative relationship between economic development and informalization has been challenged on a number of fronts. Informal work has been shown to have been widespread during $19^{\text {th }}$ century industrialization in the U.S. and Europe, particularly among women and children (Stansell 1983, John 1986). While the factory system did expand rapidly, informal activities could thrive in the context of on-going capitalist development and were often directly linked to the growth of the formal industrial economy. Thus, while the relative size of the informal economy certainly expanded and contracted over time, informal activities did not represent simply a transitional stage on the path to higher levels of economic development.

In our contemporary era, the growth experience of many developing economies has demonstrated that sizeable informal economies can co-exist and sustain themselves side-by-side with the expansion of the formal economy (Castells and Portes 1989, Benería 1989). But these informal activities are not simply lingering vestiges of "backwardness." In fact, even the expansion of foreign direct investment and global production networks has supported informal production processes. This is because, in many situations, multinational firms are seeking lowcost and "flexible" labor relations in their production-level operations. They achieve this through sub-contracting many of their production-level activities to firms operating in the informal economy. At the same time, workers employed directly by multinationals are much more likely to enjoy a more formal working environment.

Cross-country comparisons generally reveal a negative correlation between measured rates of informalization and the level of per capita GDP (see, for example, Ihrig and Moe 2000, Loayza 1996). That is, informal employment as a fraction of total employment is smaller for

\footnotetext{
3 It is not uncommon for individuals with formal sector jobs to also participate in the informal sector. In some cases, the income earned by formal employment allows participation in the informal sector. This phenomenon of individuals with income generating activities in both the formal and informal sectors is common to developed economies (see Pahl 1985) and developing economies (see Hart 1973).

4 The characterization of such unemployment often varies from situation to situation. In countries with some degree of social protection for people who can not find work, individuals are frequently classified as openly unemployed. In economies without such social protections, the unemployed, particularly those who are not supported by family and community networks, can be classified as being engaged in subsistence activities, in which case they would be grouped as part of the informal economy.
} 
more advanced industrial economies than for developing countries. However, a broad crosscountry comparison using levels of per capita output tells us little about the relationship between informalization and economic development over time within a particular country. More specifically, such correlations reveal nothing about how informal employment might respond to changes in elements of the economic and institutional environment - including shifts in the rate at which the formal economy is expanding.

Indeed, recent research has begun to document a world-wide resurgence of informalization beginning in the 1970s and continuing on into the 1980s and 1990s (ILO 2002a, Benería 2001, Charmes 2000, Castells and Portes 1989). The growth of informal work was initially attributed to the declining growth trend of capitalism associated with the end of the "golden age" in the 1970s. But this explanation does not account for the sustained presence, indeed the expansion, of the informal economy in many countries, even during times of economic growth, when the formal sector was itself also expanding. This leaves us with a perplexing puzzle: What could explain the reemergence of informalization in late $20^{\text {th }}$ century capitalist development?

Recent explanations of the growth of informal employment focus on the institutional context within which informalization takes place. In particular, most current theories of informalization incorporate a role for government regulations and formal institutional structures as they impose costs and constraints on economic actors - particularly firms and the selfemployed. The growth of the informal economy, therefore, is the result of the higher costs business firms face through operating formally.

However, the two dominant theoretical approaches to informalization adopt distinct interpretations of how these regulatory differences affect informal activities (Weiss 1987). ${ }^{5}$ On one side, informalization is seen as a reaction to the excessive distortions caused by government interference in a market economy-what we will term an overregulation-centered theory of informalization

On the other side, informalization is seen as the outcome of normal profit-seeking activity by capitalist firms, in which more flexible employment relationships produce cost reductions while they also undermine labor protections, social security measures, and labor's bargaining power. But what makes these normal competitive pressures produce a higher proportion of informal jobs is the neoliberal policy environment, which has meant both more market-oriented policies and slower economic growth. Slower economic growth, in turn, reduces economic opportunities and lessens the pressure to offer decent jobs, regardless of whether the regulatory environment requires decent work standards. The alternative approach thus sees the rise of informalization as resulting broadly from the corresponding rise of neoliberalism, and we can thus term this approach a neoliberalism-centered theory of informalization.

\section{Overregulation and informalization.}

This view is most commonly associated with the work of Peruvian economist Hernando de Soto $(1989,2000)$. According to this approach, informalization reflects pent-up

\footnotetext{
5 In contrast to the two dominant analyses, Weiss (1987) herself argues, within the context of the Italian economy, that the viability of informal economic activities depends on the impact of state bureaucracies coupled with aspects of the social and institutional structure, including the degree of labor market segmentation, the prevalence of social networks, and the availability of capital among a large number of relatively small firms.
} 
entrepreneurship that cannot find expression in an improperly regulated economy due to the high transactions costs of operating in the formal economy. Since the informal economy is, by definition, free of these constraints, the expansion of these activities is indicative of the distortionary effects of government intervention. Those working in this tradition emphasize the need to develop less costly and intrusive regulatory regimes dominated by political groupings seeking special advantages through their government connections.

Within this approach, some researchers have examined in depth the connections between transaction costs, the legal structure, and informalization (ILO 2002a). They emphasize that regulation of economic activities has a dual character: (1) it imposes costs on individual firms and workers, but (2) provides public goods and corrects for market imperfections. This distinction has been used to explain why informalization is common among small-scale firms or within laborintensive activities. For small firms and the self-employed, the transactions costs of formal regulation are likely to exceed the benefits these firm derive from the legal system. However, as firms grow in size or become more capital-intensive, the need to participate in social institutions that protect property, enforce contracts, provide access to low-cost credit, or pool risk expands. When the benefits of formality outweigh the costs, rates of informalization can be expected to decline (Levenson and Maloney 1998, Loayza 1996, Sarte 2000, Ihrig and Moe 2001, de Soto 2000, 1989).

The overregulation-centered approach does generate useful insights into how a prevailing regulatory environment can influence pressures toward informalization. But this perspective overlooks some major facts about the historical conditions in which informalization has been rising. The most directly salient is that government regulations in developing countries - in the areas of labor markets specifically but more generally as well - have been declining over the past two decades as informalization has risen. The incentives to circumvent the government's regulatory structure should therefore also be diminishing. Thus, the overregulation-centered approach only sharpens the basic question: why should informalization be increasing when, on the basis of this perspective, the incentives for doing so are declining?

\section{Neoliberalism and informalization}

The rise in informalization has coincided not simply with the decline in government regulations of labor markets, but with a broader transformation of the economic policy environment in developing countries, away from the developmental state policies that were dominant in the 1950s and 1960s, in favor of what has been termed "neoliberalism" (Pollin 2003, 1998). Neoliberalism, as its name conveys, is a variant of classical liberalism, the political philosophy that embraces the virtues of free market capitalism and the corresponding minimal role for government intervention. In developing countries, neoliberalism has involved privatization, sharp cuts in government spending and barriers to international trade, and a decline in the regulation of financial markets as well as labor markets.

The neoliberal policy approach can explain rising informalization through several mutually reinforcing channels.

1. Decline in public employment. Probably the most stable source of formal employment - in many advanced economies as well as most developing economies — has been the public sector. Because a major premise of neoliberalism is a reduction in size of the public sector, this correspondingly means that government workers lose their jobs when such policies are implemented. The proportion of formally employed workers will necessarily fall each time governments cut their workforce unless, of course, the private economy is increasing its supply of 
formal jobs at the same rate that the government sector is contracting. But in fact, as we continue to enumerate, neoliberal policies also encourage a decline in formal employment in the private sector as well.

2. Promotion of trade and foreign direct investment. The promotion of success in export markets and the ability to attract foreign direct investment is a fundamental element of a neoliberal strategy. Maintaining low labor costs is generally regarded as a central feature-and often the single dominant element - for successfully promoting exports and multinational investment. Thus, in the name of encouraging trade and foreign investment, the explicit goal of government policy under this policy regime will be to limit the ability of workers to capture the benefits of productivity improvements as increases in employment income, to reduce social and legal protections, and to weaken workers' bargaining power - that is, to induce workers to accept jobs with lower pay. The competitive pressures resulting from increasing an economy's degree of international integration will further strengthen these tendencies. Furthermore, pressures to increase the productivity of currently employed workers will reduce the number of employment opportunities generated by a given level of output growth, thereby limiting the growth of formal employment relative to informal employment.

3. Macroeconomic policy strategy. Neoliberal macroeconomic policies have entailed the abandonment of fiscal and monetary interventions by governments that attempt to explicitly promote the expansion of job opportunities - what used to be termed "full employment" macroeconomic policies. Instead, the dominant priority for macroeconomic policy has become control over inflation, and indeed, an explicit policy aimed at "inflation targeting" has become the focus in many developing countries. The logic of the neoliberal policy program argues that controlling inflation is the basis for attaining a stable macro environment in which market forces will produce efficient allocations of economic resources. As such, where governments in developing countries had formerly used fiscal and monetary policies to increase overall demand and thereby to expand job opportunities, at present governments deploy these same fiscal and monetary tools to restrain overall demand - that is, to deliberately impose slow growth and, as considered necessary, austerity — in order to prevent the build up of inflationary pressures (Epstein 2002).

At the same time, this neoliberal approach to macroeconomic management does include a policy mechanism for addressing problems of unemployment. This is the deregulation of labor markets, i.e., an increase in the so-called "flexibility" of labor markets. As a general proposition, when labor markets are more flexible, workers have to accept jobs at lower wages and under worse conditions. The unemployment problem is thereby "solved" through workers being willing to accept less desirable jobs. Here is where the parallel phenomena of informalization and neoliberalism become joined. From the standpoint of neoliberal economic policy, informalization is not an unfortunate side-effect of other policy initiatives. It is rather a conscious policy outcome in itself. In other words, informalization and increased labor market flexibility are simply two ways of observing precisely the same phenomenon.

4. Increased pressures for engaging in paid employment. When the supply of decent formal jobs declines and economic growth slows, this means that households need more people bringing home income to prevent a decline the household's living standard. Women constitute a majority of workers in the informal economy. In many instances, this form of employment for women has brought an improvement in overall household living standards as well as gains in women's independence. It is true, moreover, that the informal economy can, at times, offer women greater flexibility in terms of both hours of work and the ability to remain at home while working. At the same time, women increasingly seek paid employment in the informal economy 
as a means of preventing the downward ratcheting of living standards for households that are already living in poverty.

5. The vicious cycle. The factors listed above, especially as they operate in combination, strengthen the bargaining position of business, enabling them to hire, or contract with, workers at lower wages, benefits and protections virtually across the board - that is, to increasingly transform what had been formal work environments into informal ones. Of course, such factors will not always be dominant, especially when businesses need to hire various types of skilled workers. But for most types of employment in developing economies, the rise of informalization will feed upon itself as the bargaining power of workers weakens.

How do these general perspectives play out with respect to the available evidence on the rise of informalization? This is the question to which we next turn.

\section{Empirical Evidence on the Rise of Informalization}

Reliable data on informal employment will necessarily be limited. The very nature of the informal economy - representing those economic activities that lie outside of the formal regulatory sphere and that remain largely unrecorded - implies that even the most rigorous official techniques for measuring economic activity are able to only broadly approximate the extent of the informal economy. Estimates for Gross Domestic Product (GDP) do make allowance for informal activities. But the modeling techniques utilized for generating these estimates differ from country to country (Bloem and Shrestha 2000), thus diminishing the reliability of any cross-country comparisons. Time series data on informal employment are also of limited availability. This makes it more difficult to explore the crucial connections we have drawn between informalization and economic growth. Given all of these factors, the evidence we present here, using the available data, should be taken as only provisional.

We rely on two data sources - time series figures for Latin America in the 1990s generated by the ILO's regional office in Lima, Peru and the research of Professor Jacques Charmes of the University of Versailles on a broader set of countries, though without a year-toyear time-series component. These two sources also employ different techniques for measuring informal employment. And while both sources have clear limitations, fortunately their weaknesses are distinct, such that, in combination, we obtain a variegated understanding of the overall patterns of informalization. We first present results using the ILO data, then consider the evidence from Charmes.

\section{ILO Data for Latin America}

The first data source we draw on comes from the ILO's regional office in Lima. These figures present statistics on informal employment in Latin America over the 1990s. However, these figures work with the earlier concept of a distinct informal sector as opposed to a process of informalization applying, at least potentially, across sectors. According to this data set, those employed in the informal sector includes all own-account workers, excluding professionals and paid domestic workers, and persons working in establishments with less than 5 or 10 employees, depending on the survey methodology used. These data have clear limitations, as the ILO itself now recognizes. Most importantly, they do not incorporate in their measure forms of informal employment that occur outside of small-scale enterprises. Home-based laborers, for example, are excluded from their definition. The ILO has more recently begun to operate with a more expansive approach, reflecting the shift in analytic thinking from the notion that informal jobs are 
confined within certain sectors of the economy to the process of informalization occurring more broadly throughout a range of sectors (ILO 2002b). ${ }^{6}$ Despite this weakness in this data set, the absence of alternative, better sources means that it is still an important resource. So we turn to these figures to obtain a first approximation of changes that have occurred over the 1990s in the extent of informal employment.

Figure 1 summarizes information on changes in informal employment as a percent of total non-agricultural employment — which we will term as a country's "informalization rate"and the rate of growth of GDP for 10 Latin American countries from 1990 to 1997. Table A1, in the appendix to this paper, presents the data used to construct this figure.

The trends presented in Figure 1 contradicts the idea of a purely counter-cyclical explanation for the rise of informalization, in which informal employment grows during economic slumps and shrinks during periods of growth. While sharp economic downturns are generally associated with an expansion of the informal sector (for example, Costa Rica 1996, Honduras 1994, Mexico 1995, Venezuela 1994), this is a relatively isolated phenomenon. More generally, there has been a trend in almost all these countries towards greater informalization even during periods of relatively rapid economic growth. In some cases, informalization appears to rise and fall with changes in the growth rate (e.g. Costa Rica). However, even in these cases, informalization increases on average over periods of expansion.

\section{The Charmes data set}

Professor Jacques Charmes of the University of Versailles has developed a highly innovative but still straightforward methodology for measuring trends in the size of the informal economy (see, for example, ILO 2002b, Charmes 2000). Charmes measures the number of workers in the informal economy as the residual that emerges from two data sets in various countries: 1) Labor force surveys and censuses, which are intended to measure all people engaged in income-generating forms of employment; and 2) Business registration data, in which businesses are supposed to list all employees in their enterprises.

According to Charmes' definition, therefore, people who are informally employed are those who earn income from jobs, but they are not employed by a business that officially registers their enterprise with the government. This definition may, in fact, underestimate the extent of informalization, because some businesses that provide business registration information to governments may operate with substandard work environments for employees. Moreover, for Charmes to effectively utilize the methodology he has developed obviously depends, first, on countries' having undertaken both pairs of surveys at least twice in recent years. In Table 1 below, we report the basic evidence Charmes provides from the countries that meet these criteria and he could therefore incorporate into his survey.

\footnotetext{
6 Nevertheless, these measurements are consistent with the approach outlined in 1993 at the $15^{\text {th }}$ International Conference of Labor Statisticians (ICLS). The 1993 ICLS definition of the informal economy adopted an enterprise approach (defining informal activities in terms of production units) as opposed to a labor approach (defining informal status on the basis of individual characteristics). This decision was based on a need to measure the economic contribution of the informal sector, not simply the level of employment. However, an enterprise approach would not capture all aspects of informalization. Therefore, workers would be classified into informal and formal sectors by their status in employment as identified in the International Classification of Status in Employment (ICSE). A combination of data on status in employment and enterprise type can be used to map the informal economy and the level of employment.
} 
Figure 1. Economic Growth and Informalization in Latin America, 1990 - 97
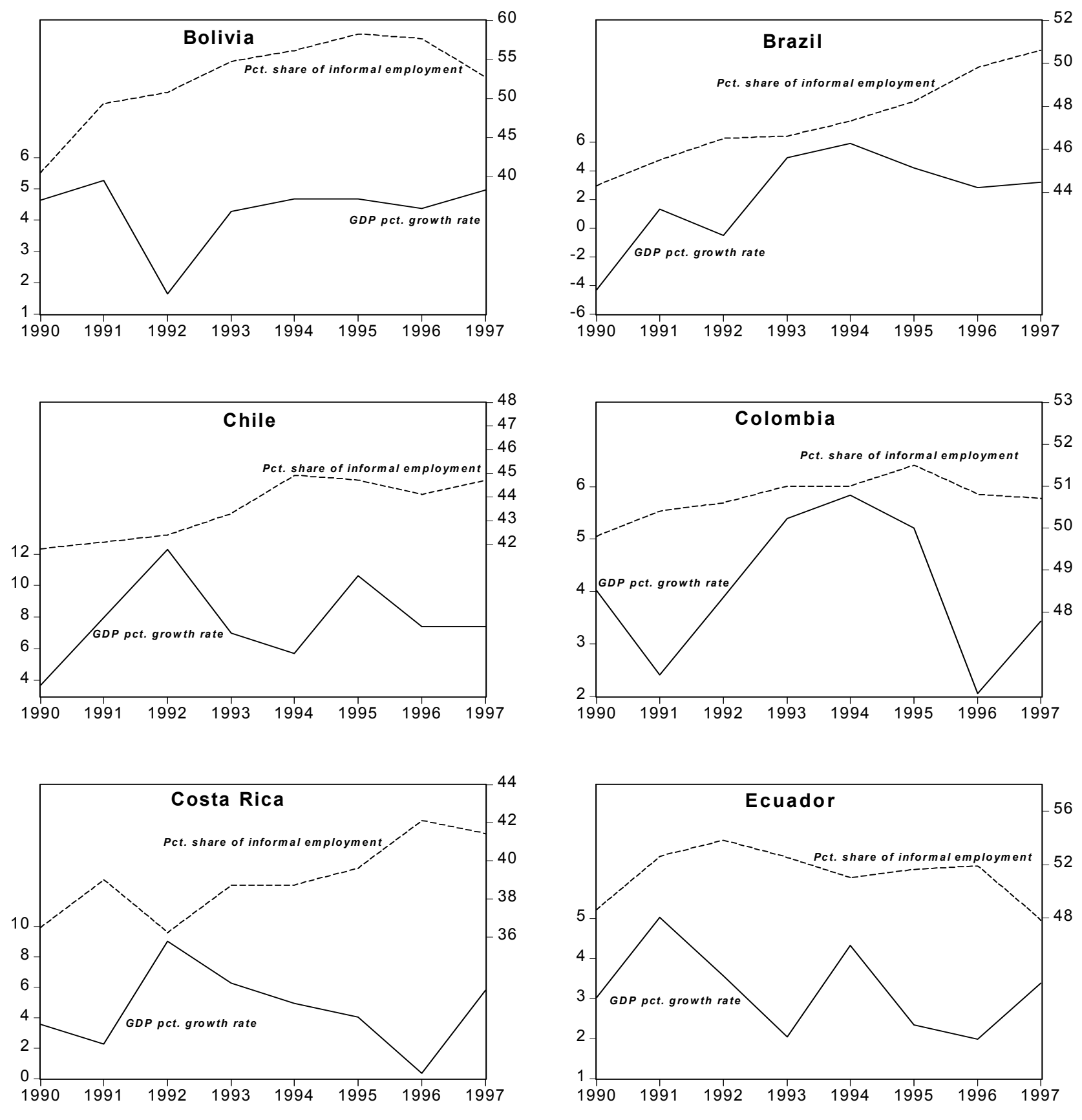
Figure 1 continued

Economic Growth and Informalizaton in Latin America
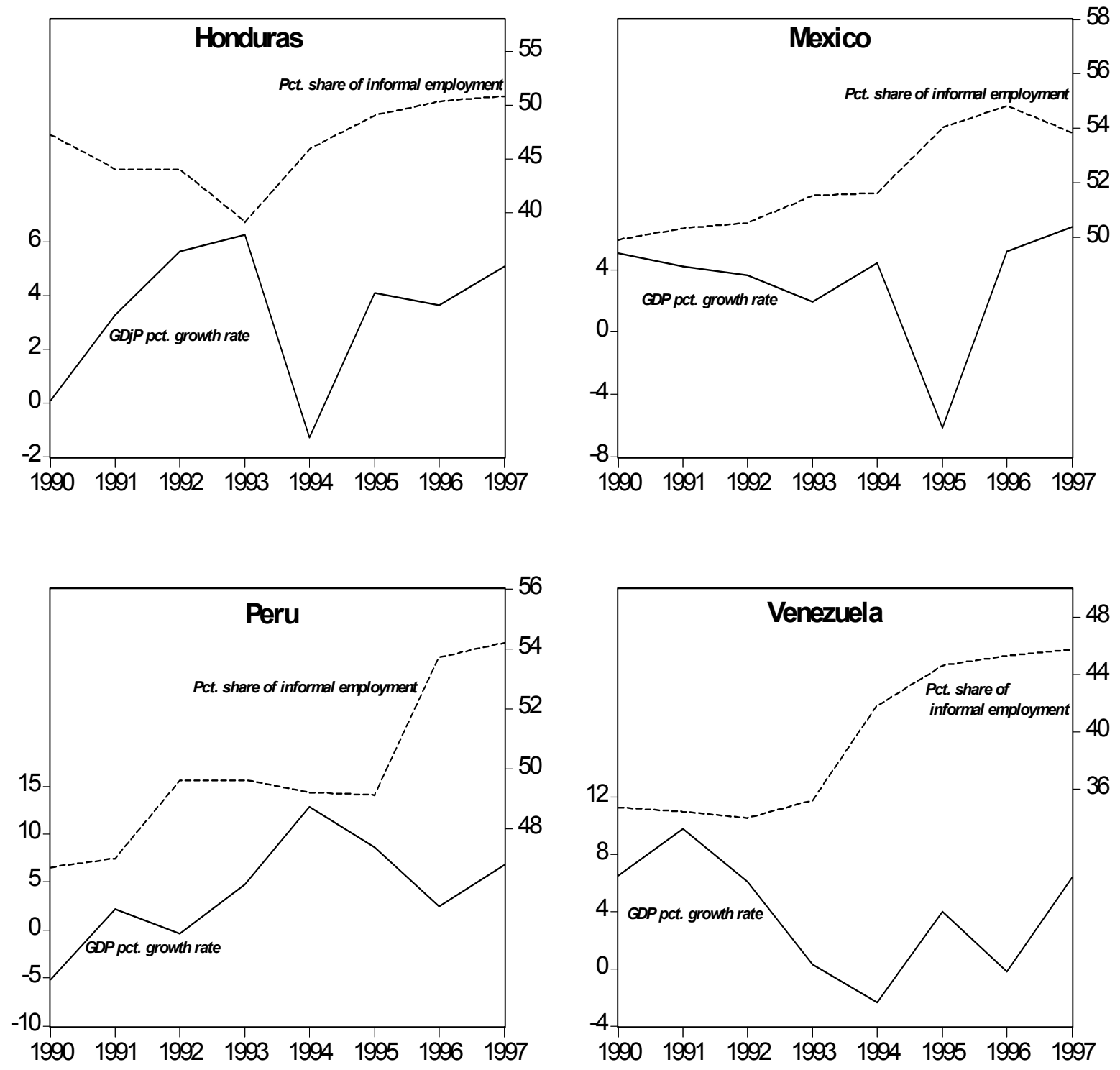

Sources: ILOKey Indicators of Labor Markets 2001/2 CD-ROM and World Bank, World Development Indicators 2001 CD-Rom 
TABLE 1. INFORMAL EMPLOYMENT IN LESS DEVELOPING COUNTRIES

\begin{tabular}{|c|c|c|c|}
\hline Country & Years of Data Samples & $\begin{array}{l}\text { Informalization } \\
\text { rate during sample } \\
\text { years (percentages) }\end{array}$ & $\begin{array}{c}\text { Ave. annual change in } \\
\text { informalization rate } \\
\text { (percent) }\end{array}$ \\
\hline \multicolumn{4}{|c|}{ Countries with 5 years or less as observation period } \\
\hline 1) Argentina & $1990-95$ & $47.5 \rightarrow 53.3$ & +1.2 \\
\hline 2) Bolivia & $1990-95$ & $56.9 \rightarrow 63.6$ & +1.3 \\
\hline 3) Brazil & $1990-95$ & $52.0 \rightarrow 57.6$ & +1.1 \\
\hline 4) Chad & $1993-96$ & $72.4 \rightarrow 90.0$ & +24.3 \\
\hline 5) Colombia & $1990-96$ & $55.2 \rightarrow 55.5$ & +0.06 \\
\hline 6) Ecuador & $1990-95$ & $51.2 \rightarrow 53.5$ & +0.9 \\
\hline 7) Indonesia & $1996-98$ & $75.6 \rightarrow 77.7$ & +1.4 \\
\hline 8) Mexico & $1990-95$ & $55.5 \rightarrow 59.4$ & +1.4 \\
\hline 9) Paraguay & $1990-95$ & $61.4 \rightarrow 65.5$ & +1.3 \\
\hline 10) Venezuela & $1990-95$ & $38.8 \rightarrow 46.9$ & +4.2 \\
\hline \multicolumn{4}{|c|}{ Countries with 6 - 10 years as observation period } \\
\hline 11) Burkina Faso & $1985-94$ & $70.0 \rightarrow 77.0$ & +1.1 \\
\hline 12) Guinea & $1984-91$ & $64.4 \rightarrow 71.9$ & +1.3 \\
\hline 13) Kenya & $1990-99$ & $61.4 \rightarrow 71.6$ & +1.8 \\
\hline 14) Mauritania & $1980-88$ & $69.4 \rightarrow 80.0$ & +1.9 \\
\hline \multicolumn{4}{|c|}{ Countries with more than 10 years as observation period } \\
\hline 15) Algeria & $1977-97$ & $21.8 \rightarrow 42.7$ & +4.8 \\
\hline 16) ndia & $1989-2000$ & $76.2 \rightarrow 83.4$ & +0.9 \\
\hline 17) Mali & $1976-96$ & $63.1 \rightarrow 90.4$ & +2.2 \\
\hline 18) Pakistan & $1975-90$ & $39.0 \rightarrow 64.6$ & +3.1 \\
\hline 19) Tunisia & $1975-89$ & $38.3 \rightarrow 39.3$ & +0.2 \\
\hline
\end{tabular}

B) COUNTRIES WITH DECREASING RATES OF INFORMALIZATION

\begin{tabular}{|l|r|r|r|}
\hline \multicolumn{1}{|c|}{ Country } & Years of Data Samples & $\begin{array}{c}\text { Informalization } \\
\text { rate during sample } \\
\text { years (percentages) }\end{array}$ & $\begin{array}{c}\text { Ave. annual change in } \\
\text { informalization rate } \\
\text { (percent) }\end{array}$ \\
\hline \multicolumn{5}{|c|}{ Countries with 6-10 years as observation period } \\
\hline 20) Phillipines & $1990-97$ & $70.5 \rightarrow 67.6$ & -0.6 \\
\hline 21) Thailand & $1990-98$ & $54.5 \rightarrow 50.6$ & -1.9 \\
\hline 22) Egypt & $1976-86$ & $65.3 \rightarrow 58.7$ & -1.6 \\
\hline \multicolumn{5}{|c|}{ Countries with more than 10 years as observation period } \\
\hline 23) Morocco & $1982-95$ & $56.9 \rightarrow 44.8$ & 0.9 \\
\hline
\end{tabular}

As we see, there are 23 developing countries in the survey. Among the countries, there are significant differences in the length of time-period between available data points. With 10 of the countries, the longest time period over which we have data is five years or less. But we do also have a relatively large sample of countries for which we have a longer period to examine- 
six countries for which our time span between data points is $6-10$ years and seven countries with 10 or more years between data points. This range in Charmes' data set does therefore, in our view, provide sufficient variation such that we may obtain some reliable generalizations from studying it.

We have organized the data into two broad groups - those for which informalization has increased over time, and those where it has decreased. Within these broad categories, we then group the countries according to the length of time between the most distant and recent data points from the surveys utilized by Charmes.

Patterns of informalization. Informalization is growing over time in 19 of the 23 countries in the sample. This is particularly true in countries where the observed time period is five years or less. In these cases, all 10 of the countries experienced rising rates of informalization. In the countries where our data points are between $6-10$ years apart, we have the most balanced situation, in which four of the countries experienced increasing rates of informalization while three countries experienced declining rates. Moreover, the three countries experiencing declining rates of informalization all have large populations, while three of the four countries experiencing increasing rates of informalization are small. Finally, in cases where our time period between data points is more than 10 years, we have five countries with increasing rates of informalization, including India and Pakistan with large populations, while only one country, Morocco, experienced a decline in the proportion of informal employment.

Overall, we can conclude: 1) Informal employment is clearly the predominant form of employment in developing countries; and 2) It is generally rising as a share of overall employment. These broad conclusions cut across regions and countries of various sizes.

\section{Informalization and Economic Growth}

As we have discussed above, the rise of neoliberal policies in developing countries have generally led to a decline in average rates of economic growth. We can see this from the aggregated evidence in Table 2, which compares average growth rates in two distinct eras in developing countries - what we may term the "developmental state" era of roughly 1960 - 1980; and the "neoliberal era" from 1981 - 1999 (and continuing to the present). The figures are presented both in terms of overall GDP data and measuring growth on a per capita basis. The table also includes China separately since it had not pursued a neoliberal policy path by the end of the 1990s. ${ }^{7}$ Otherwise, these figures are calculated by adding up the overall GDP figures for all low and middle-income countries. This way, the patterns for large countries, like India, Brazil, or Egypt will carry more weight in the calculations than those for small countries like Bolivia, Uganda or Singapore.

The overall growth pattern is unambiguous: there has been a sharp decline in growth in the neoliberal era relative to the developmental state period, from 5.5 to 2.6 percent, measured on average annual basis. Measured on a per capita basis, the downward growth trend is even more dramatic, with the growth rate in the neoliberal era at only 0.7 percent. This means that that the average increase in overall income in the poor and middle income countries just barely stayed

\footnotetext{
${ }^{7}$ It is also true that when we include China within the group of low and middle income countries, the overall growth patterns we observe are modified but do not change dramatically. Thus, per capita GDP growth for low and middle income countries including China is 3.2 for 1961-80 and 1.4 for 1981-99.
} 
ahead of population growth, after having increased 3.2 percent faster than population growth during the developmental state period. ${ }^{8}$

TABLE 2.

TWO ERAS OF ECONOMIC GROWTH IN DEVELOPING COUNTRIES (figures are average annual growth rates, in percentages)

\begin{tabular}{|c|c|c|}
\hline & $\begin{array}{c}\text { Developmental State Era } \\
\mathbf{1 9 6 1 - 8 0}\end{array}$ & $\begin{array}{c}\text { Neoliberal Era } \\
\mathbf{1 9 8 1 - 9 9}\end{array}$ \\
\hline $\begin{array}{l}\text { Low and Middle Income } \\
\text { Countries, Excluding China }\end{array}$ & & \\
\hline Overall growth rate & 5.5 & 2.6 \\
\hline Per capita growth rate & 3.2 & 0.7 \\
\hline China & & \\
\hline Overall growth rate & 4.5 & 9.8 \\
\hline Per capita growth rate & 2.5 & 8.4 \\
\hline
\end{tabular}

Source: World Development Indicators 2001 CD-ROM, World Bank

What has been the relationship between growth and informalization? As an initial consideration of this, we show in Figure 2 the relationship between average annual GDP growth per capita and informalization for the 20 countries in the sample for which adequate data exist for both informalization and per capita growth over a sufficiently long time period. ${ }^{9}$ Of course, again, these calculations represent different periods of time within the various countries. From the data plot, we can see that there is an inverse relationship between informalization and economic growth. For the most part, informalization does fall as economic growth rises. The relationship is not statistically significant, however. Still, the overall results are being strongly influenced by the experience in Argentina. From 1990 - 1995, Argentina experienced a rapid increase in informalization. But it was also experiencing the most rapid period of economic growth of the countries in the sample. This growth was due to a massive influx of foreign capital into Argentina after the country adopted a new extreme neoliberal monetary policy whose principal feature was establishing the country's currency as convertible to the U.S. dollar on a one-for-one basis. The positive effects of the Argentine monetary convertibility plan were shortlived. By 1997, foreign capital began to abandon Argentina, and by 2000, the new monetary policy engendered a complete financial collapse and depression in the country. But for our purposes, Argentina during 1990-95 clearly stands as a major outlier in our sample.

\footnotetext{
${ }^{8}$ Growth patterns do vary significantly by region, with various parts of Asia, including India, performing much better than Latin America or Africa prior to the Asian financial crisis of 1997-98. The table also shows the unique experience of China, where the average growth rate more than doubled during the 198198 period relative to 1961-80. The general pattern, nevertheless, is clear-cut, and it will form a major starting point to our analysis.

${ }^{9}$ The three countries excluded from the original 23 are Guinea, because of inadequate per capita growth data; and Chad and Indonesia, because of overly short time series).
} 


\section{Figure 2. Average rates of per capita GDP growth and annual changes in informalization}

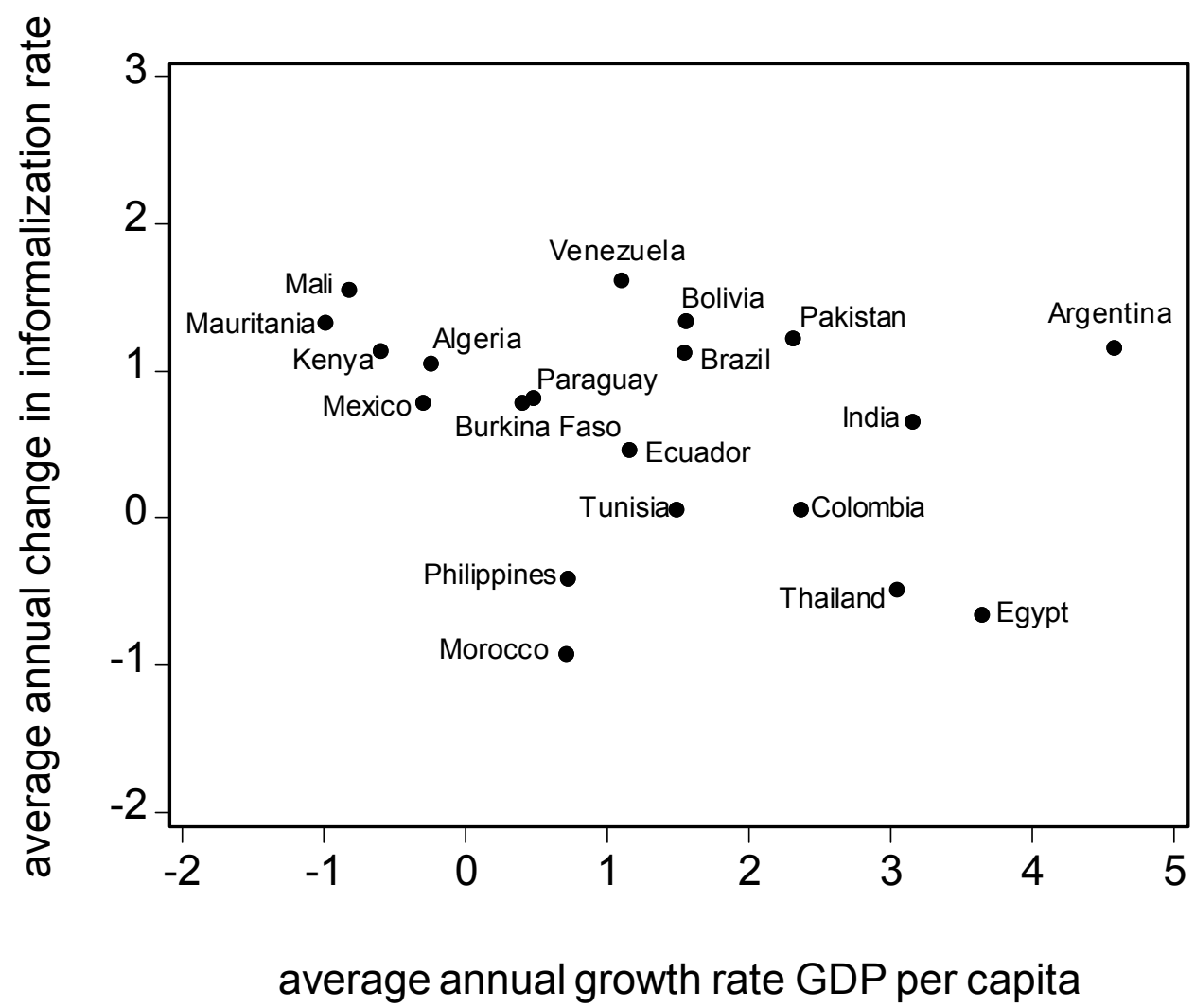
Source: Updated informalization rates estimated by Jacques Charmes, 2003;
World Development Indicators 2001 CD-ROM, World Bank

If we eliminate Argentina from the sample as an outlier, and re-estimate the regression line with the remaining 19 countries, this yields a negative slope estimate $(-0.27)$ with a much higher degree of statistical significance $(p$-value $=0.0397)$. The coefficient value of -0.27 suggests that an increase in the rate of per capita economic growth from the average of 0.7 percent associated with the neoliberal era to the 2.6 percent associated with the developmental era (see Table 2) - an increase of 1.9 percent - would reduce the annual rate of change in the informalization rate by 0.51 percentage points. Taking our median values for highs and lows among the countries in the sample, a sustained average increase in economic growth of 1.9 percent would mean that instead of informal employment rising from an average of 55 to 65 percent of the workforce, over the course of a decade informal employment would instead rise to slightly less than 60 percent. Figure 3 shows changes in informalization and average growth rates with Argentina removed from the sample, with the line in the figure portraying the regression slope of -0.27 . 


\section{Figure 3. Average rates of per capita GDP growth and annual changes in informalization (Argentina excluded)}

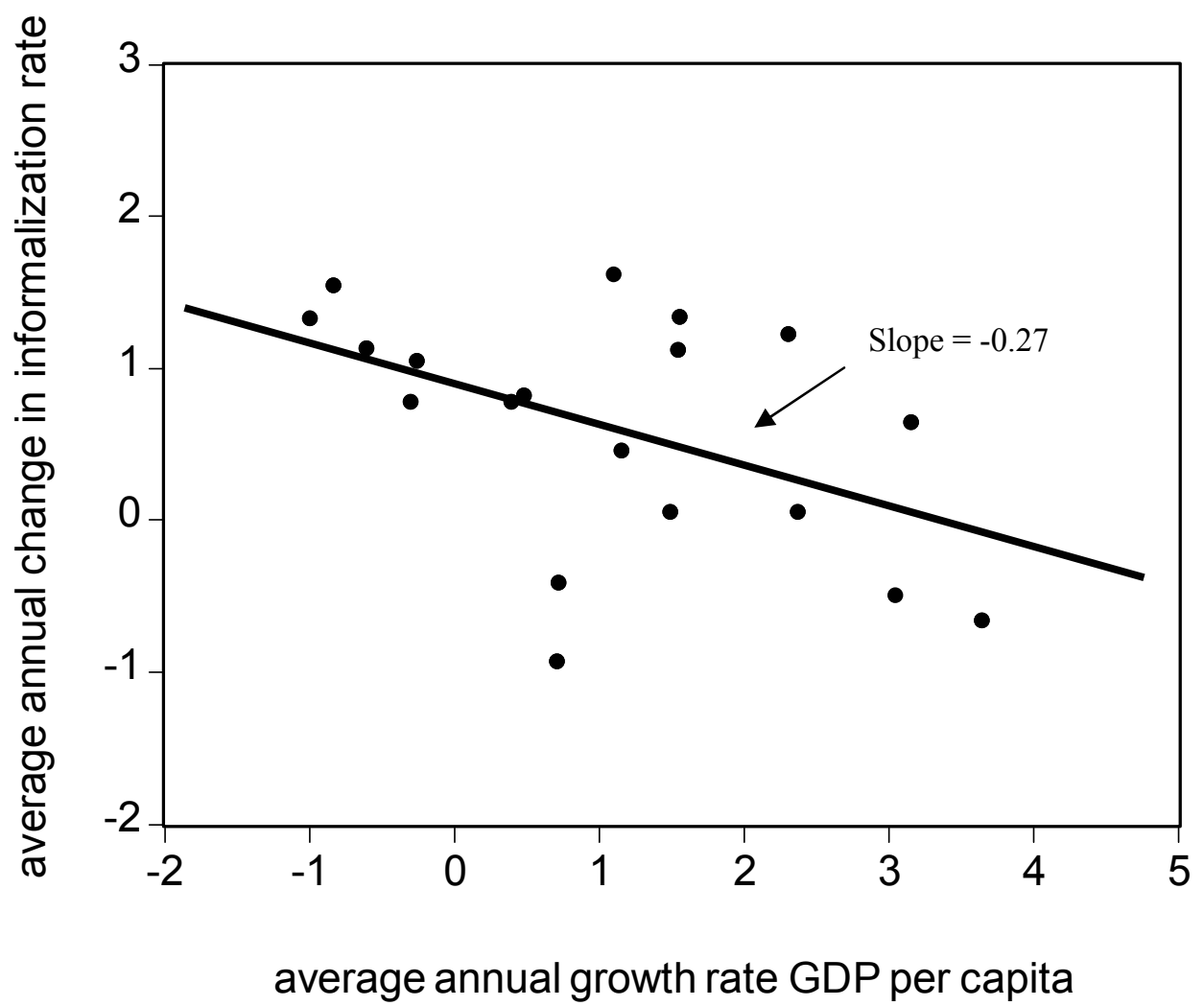

Source: Updated informalization rates estimated by Jacques Charmes, 2003; World Development Indicators 2001 CD-ROM, World Bank

Overall, we can conclude provisionally from this brief examination that increasing economic growth will reduce the rate at which informalization is increasing in developing countries, though it cannot, on its own, create an environment in which informalization actually declines.

Both supply and demand factors within the labor market are likely contributing to the diminished rate of increase in informalization. On the demand side, high rates of economic growth means that businesses are expanding their operations. To attract workers, they need to offer workers better wages, benefits and social protections, i.e. to formalize jobs, even if the regulatory environment does not require them to do so. On the supply side, better opportunities available to workers for formal jobs makes them less willing to accept informal employment. Also, when some household members earn higher incomes from formal jobs, the pressures diminish for others in the household to also earn income by entering the informal labor market. 
Considering our examinations based on both the ILO and Charmes data sets, we are able to form some useful, if still necessarily provisional, generalizations about the relationship between informalization and economic growth. First, the evidence reported here does not support a purely counter-cyclical model of informal employment, in which the informal economy consists of the residual reserve army of workers that are not employed in formal activities during periodic slumps. Second, although informal employment does not exhibit a clear counter-cyclical pattern, sharp downturns still emerge as being closely associated with a rise in informal employment.

Third, increasing rates of informalization are consistent with positive average rates of economic growth. And finally, the weight of evidence does suggest that, after controlling for short-term cyclical factors, high rates of economic growth are associated with either declines in informalization or slower rates at which informalization is increasing.

\section{Improving labor standards in the context of informalization}

If we recognize informalization as a process operating throughout an economy rather than as confined to a limited set of sectors, this implies that improving labor standards will entail the reversal of this broad process of informalization. The evidence we have reviewed strongly supports the view that reversing the process of informalization will require a substantial shift away from the priorities defined by neoliberalism - in particular, the priorities of targeting inflation over economic growth; and the reliance on "flexible labor markets" as the basic instrument of addressing employment problems. What is rather needed are 1) a macroeconomic policy framework that targets employment growth while still recognizing the need for inflation control; and 2) a set of labor standards that can operate to improve working conditions broadlythat is to say, which improves condition for those in both formal and informal employment situations.

Examining these matters in detail are beyond the scope of this paper. But it will be useful to consider the matter of how to effectively introduce labor standards that will have the broadest possible effects. Introducing standards that will affect informal as well as formal employment situations is of crucial importance, as the overregulation-centered analysis of informalization itself makes clear. If regulations apply only to forms of employment that are already more formalized, this will simply raise the relative costs of operating formally and increase the incentives for firms to circumvent regulations - that is, to informalize their work environment.

The first step toward designing effective interventions to improve conditions in informal forms of employment is to recognize the heterogeneity of informal activities. For example, consider the case in which informal workers are able to capture the majority of the value-added they produce. These activities could include the self-employed producing directly for the domestic market or community-based enterprises in which the value-added is not appropriated. Under such conditions, interventions that increase labor productivity in the informal employment will raise living standards, since workers will be able to capture the gains of the productivity improvements. Targeted policies to improve productivity could include access to credit and capital, educational programs for skill enhancement, and infrastructure development (e.g. electrification).

However, if the informal economy is primarily composed of wage and pseudo-wage (e.g. piece-work) employment relationships with ties to a more extensive commodity chain, then focusing on productivity improvements as a strategy to raise living standards will be far less successful. When the highly competitive conditions at the level of production (or, in some cases, at the point of sale to consumers) are linked to more oligopolistic structures elsewhere in the 
commodity chain, a situation is created in which the benefits of productivity improvements will be captured in the form of higher rents for firms further up the chain or in lower prices for consumers. This unequal distribution of the gains from productive activities occurs because informal producers have little bargaining power to protect their incomes relative to other segments of the commodity chain (Carr, Chen, and Tate 2000). Firms and intermediaries that source from informal producers, including home-based workers, can demand lower prices in the face of productivity improvements or simply take their business elsewhere.

This dynamic is particularly pronounced in informal activities that produce low-wage consumer exports with explicit links to global commodity chains. In many respects, the problem of extending labor standards to informal jobs is quite similar to the more general challenge of improving working conditions and eliminating sweatshops internationally. The structure of global commodity chains is such that highly competitive conditions exist at the point of production while intermediaries, brand-name multinationals, and retailers in affluent markets enjoy significant market power (Gereffi 1994, Carr, Chen, and Tate 2000). Under these conditions, informal workers are not just competing with others in the same regional labor markets. They are competing with workers in informal workplaces around the globe.

In such a situation, the only logical strategy is to extend appropriate social protections to these informal forms of employment. However, national governments often lack sufficient capacity to enforce existing regulations in a globally integrated environment. Moreover, incentives to enforce standards are weakened when informal activities are seen to be creating jobs and economic opportunities, while labor standards are perceived as creating obstacles to employment growth.

This means that additional non-governmental measures should be nurtured to bolster governmental efforts at providing a decent regulatory environment. For example, in the case of export-oriented production, one alternative would be for the producers to implement so called "codes of conduct" governing a set core labor standards (e.g. human rights, health and safety, and a decent minimum wage). In global commodity chains, the reputation of retailers and brand-name corporations becomes a real asset. Correspondingly, having one's corporate image tarnished through associations with exploitative labor practices will likely bring more to harm profitability than the higher labor costs firms would pay to, say, clean up sweatshop conditions under which workers produce their goods. Workers and their supporters can leverage this vulnerability facing brand-name producers to create a system of incentives that would encourage multinationals to raise retail prices and share some of their rents in order to improve working conditions and pay living wages (Pollin, Burns, and Heintz 2004). Firms that guarantee that their suppliers, affiliates, and subcontractors meet the provisions of a core code of conduct would enjoy a competitive advantage in terms of consumer demand and goodwill.

Improving conditions and enforcing standards in the informal economy will naturally reduce the competitive advantage informal activities enjoy relative to equivalent formal activities. Therefore, we would expect to see a decline in the rate of informalization if such targeted interventions were successfully implemented. Returning to the informalization-growth curve of Figure 3, we could represent these targeted interventions as a downward shift in the line. That is, we would expect changes in the rate of informalization to be lower at a given rate of growth.

Figure 4 presents a stylized illustration of the combined effect of the two-pronged strategy to improve average labor standards in the context of informalization by illustrating the relationships between growth and informalization hypothesized in this paper. The heavy line, g1, represents a given rate of per capita growth. With no interventions, informalization increases at a 
rate of $i_{0}$. The impact of the shift to an employment-targeted macroeconomic policy regime is represented by a steeper slope for the informalization-growth curve, since employment targeting would mean that the rate of change of informalization would fall more rapidly as growth expands. This intervention alone would reduce the rate by which informalization increases to $i_{1}$. The effect of targeted interventions aimed at creating and enforcing better conditions for informal activities is represented by a downward shift in the line - that is, for a given growth rate, the rate by which informalization changes would be reduced. This would reduce the rate of change in informalization to $i_{2}-a$ negative number. Moreover, if the growth rate increases with the adoption of an alternative set of macroeconomic policies, then the reduction in informalization will be greater still.

\section{Figure 4. Combining Increased Growth and Improved Labor Standards to Lower the Informalization Rate}

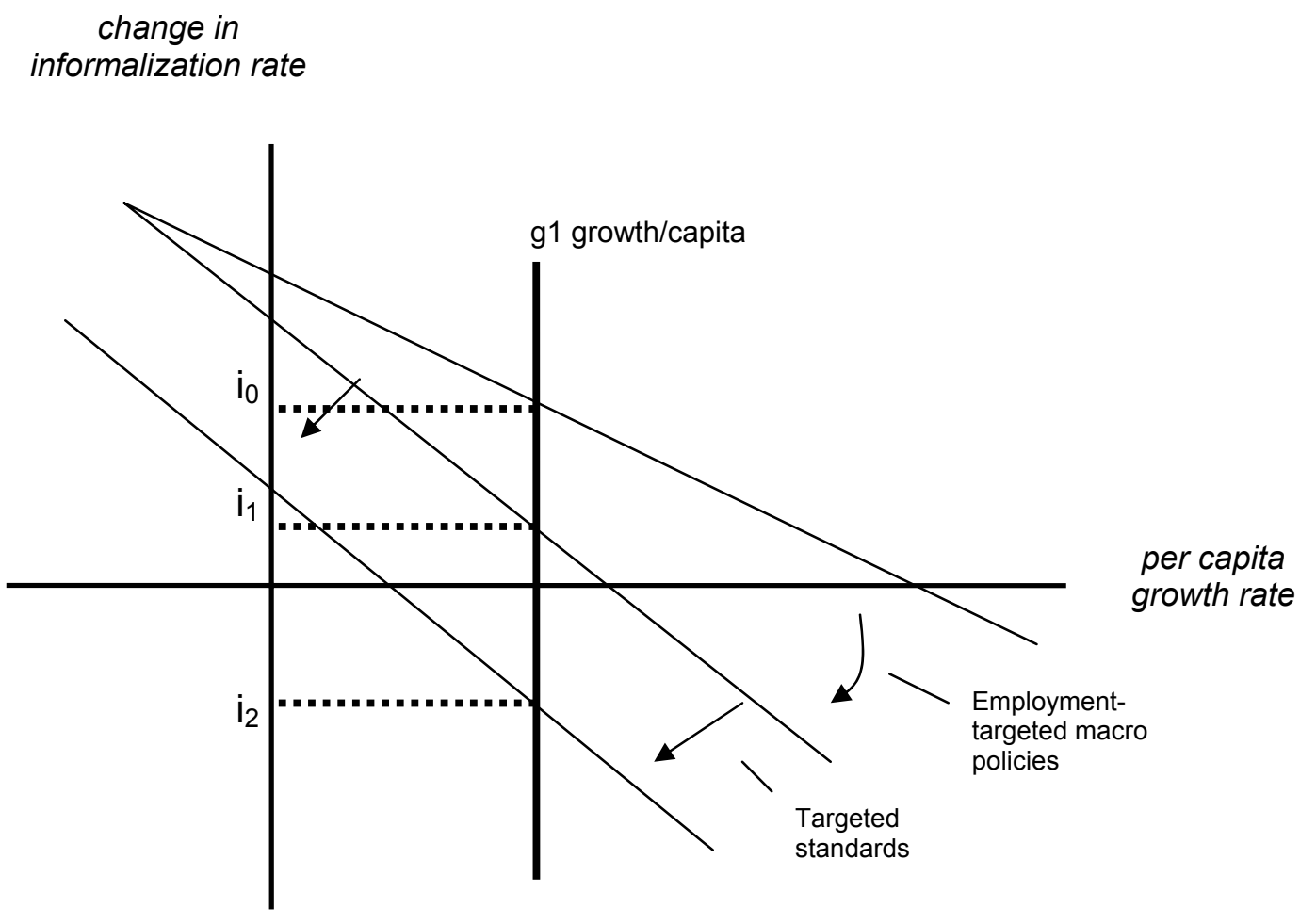

One final complication to note here is that to the extent this approach might succeed in reducing the rate of informalization, it could actually curtail economic opportunities for some workers, primarily women, who face constraints that prohibit their holding a formal job. Labor force participation of these workers is often constrained to the informal economy because of more flexible work hours and the ability to work from their homes, even when incomes might fall below what is available from formal jobs. For these workers, the loss of informal employment could produce a reduction of autonomy and bargaining power relative to those in their households who do hold jobs and earn income. However, it is never the case that formal jobs-i.e. those most likely to offer decent wages, benefits and protections - must necessarily be inflexible in terms of hours of work and possibilities for working out of the home. The aim of an effective regulatory regime would clearly be to extend social protections along the dimensions of employment 
income, benefits, and working conditions while maintaining in some situations the advantages of informal employment in terms of hours, flexibility, and location of work.

\section{Conclusions}

It is impossible to realistically discuss policies for improving living standards for the most vulnerable segments of the work force without understanding the process, proceeding throughout the less developed world, of informalization. In many countries, informal employment accounts for a majority of all labor force activity. Therefore, the growth of informalization directly compromises average employment conditions, since, on average, the quality of informal employment falls well below that of formal employment. A deterioration in the expected quality of economic opportunities will also affect working conditions outside of the informal economy by reducing workers' fallback positions and heightening their degree of vulnerability.

The spread of informalization throughout the developing world raises basic questions about the relationship between informalization and economic development. The costs associated with regulating market activity do, of course, encourage efforts to circumvent regulations. All else equal, this factor should encourage more informal work environments. But as we have argued, all else has not been equal over the past generation in developing countries. In fact, the ascendancy of neoliberal economic policies has brought a decline in government regulations, even while informalization has been rising. This suggests that an explanation for the rise of informalization centered on the effects of neoliberal policies provides a more robust explanation than one centered on the high costs of regulation.

Our empirical analysis of the relationship between informalization and economic growth produced some useful, if provisional, findings. The most important is that economic growth does encourage a decline in the rate at which informal forms of employment are growth. But economic growth does not, by itself, produce an absolute decline in the proportion of people working in informal jobs Based on these findings, we argue for a two-pronged alternative to the neoliberal policy regime. The first prong is macroeconomic policy: to substitute employment-targeted macroeconomic policies for the neoliberal priorities of inflation targeting. This policy shift should raise average rates of economic growth and encourage job expansion. The second prong is a set of labor market and related interventions that can affect working conditions in what are now both formal and informal employment situations. The purpose of these interventions will enable the gains from faster economic growth to be shared broadly, including among those who constitute the growing majority of people in developing countries earning their living in informal forms of employment. 


\section{References}

Balakrishnan, Radhika (2002), ed. The Hidden Assembly Line: gender dynamics of subcontracted work in a global economy, Bloomfield, CT: Kumarian Press.

Benería, Lourdes (2001), "Shifting the risk: new employment patterns, informalization, and women's work," International Journal of Politics, Culture, and Society, 15(1): 27-53.

Bloem, Adriaan and Manik Shrestha (2000), "Comprehensive measures of GDP and the unrecorded economy," IMF Working Paper, WP/00/204, December, Wasington, D.C.: The International Monetary Fund.

Braunstein, Elissa (2002), "Gender, FDI, and women's autonomy: a research note on empirical analysis," Working Paper 49, Political Economy Research Institute, University of Massachusetts-Amherst.

Carr, Marilyn, Martha Alter Chen, and Jane Tate (2000), "Globalization and home-based workers," Feminist Economics, 6(3): 123-42.

Castells, Manuel and Alejandro Portes (1989), "World underneath: the origins, dynamics, and effects of the informal economy," In A. Portes, M. Castells, and L. Benton, eds. The Informal Economy: studies in advanced and less developed countries, Baltimore: The John Hopkins University Press, pp. 1137.

Charmes, Jacques (2000), "Informal sector, poverty, and gender: a review of empirical evidence," Background paper for the 2001 World Development Report, World Bank, Washington, D.C.

Epstein, Gerald (2002), "Employment-Oriented Central Bank Policy in an Integrated World Economy: A

Reform Proposal for South Africa, Political Economy Research Institute, Working Paper 39.

Dangler, Jamie Faricellia (2000), "The periodic resurgence of non-factory-based production: the case of waged homework," In F. Tabak and M. Crichlow, eds. Informalization: process and structure, Baltimore: John Hopkins University Press, pp. 47-68.

Gereffi, Gary (1994), "The organization of buyer-driven global commodity chains: how U.S. retailers shape overseas production networks," In G. Gereffi and M. Korzeniewicz, eds. Commodity Chains and Global Capitalism, Westport, CT: Greenwood Press, pp. 95-122.

Gerry, Chris (1987), "Developing economies and the informal sector in historical perspective," The Annuals of the American Academy of Political and Social Science, 493(September): 100-19.

Hart, Keith (1973), "Informal income opportunities and urban employment in Ghana," The Journal of Modern African Studies, 11(1): 61-89.

Hemmer, Hans R. and C. Mannel (1989), "On the economic analysis of the urban informal sector," World Development 17(10): 1543-52.

ILO (1972) Employment, Incomes, and Equity: a strategy for increasing productive employment in Kenya, Geneva: International Labor Organization. (2002a) Decent Work and the Informal Economy, Report VI presented at the $90^{\text {th }}$ session of the International Labor Conference, Geneva: International Labor Office. (2002b) Women and Men in the Informal Economy: a statistical picture, Geneva: International Labor Office, Employment Sector.

Ihrig, Jane and Karine Moe (2001), "Tax policies and informal employment: the Asian experience," Asian Economic Journal 15(4): 369-83.

Joekes, Susan (1987), Women in the World Economy, Oxford, UK: Oxford University Press.

John, Angela (1986), "Introduction," In A. John, ed. Unequal Opportunities: women's employment in England 1800-1918, Oxford: Basil Blackwell, pp. 1-41.

Levenson, Alec and William Maloney (1998), "The informal sector, firm dynamics, and institutional participation," Policy Research Working Paper No. 1988, World Bank, Washington, D.C.

Lewis, W. Arthur (1954), "Economic development with unlimited supplies of labour," Manchester School of Economic and Social Studies, 22(2): 139-91.

Loayza, Norman (1996), "The economics of the informal sector: a simple model and some empirical evidence from Latin America," Carnegie-Rochester Conference Series on Public Policy 45: 12962 .

Meagher, Kate (1995), "Crisis, informalization, and the urban informal sector in sub-Saharan Africa," Development and Change, 26: 259-84.

Murphy, Martin (1990), "The need for a re-evaluation of the concept 'informal sector': the Dominican case," In M.E. Smith, ed., Perspectives on the Informal Economy: monographs in economic anthropology, No. 8, Lanham, MD: University Press of America, pp. 161-81. 
Nattrass, Nicoli (1987), "Street trading in Transkei: a struggle against poverty, persecution, and prosecution," World Development 15(7): 861-75.

Pahl, R.E. (1985), “The politics of work," Political Quarterly, 56(4): 331-45.

Pollin, Robert (1998) "Can domestic expansionary policies succeed in a globally integrated environment? A consideration of alternatives," in Dean Baker, Gerald Epstein and Robert Pollin eds., Globalization and Progressive Economic Policy, Cambridge, UK: Cambridge University Press, $433-60$. (2003) Contours of Descent, London: Verso forthcoming.

Pollin, Robert, Justine Burns and James Heintz (2004) "Global Apparel Production and Sweatshop Labor: Can Raising Retail Prices Finance Living Wages?" Cambridge Journal of Economics, forthcoming.

Roldan, Martha (1988), "Renegotiating the marital contract: intrahousehold patterns of money allocation and women's subordination among domestic outworkers in Mexico City," In D. Dwyer and J. Bruce, eds. A House Divided: women and income in the Third World, Stanford, CA: Stanford University Press, pp.229-247.

Sarte, Pierre-Daniel (2000), "Informality and rent-seeking bureaucracies in a model of long-run growth," Journal of Monetary Economics, 46(1): 173-97.

Sathar, Zeba and Shahnaz Kazi (1989), "Female employment and fertility: further investigation of an ambivalent association," The Pakistan Development Review, 28(3): 175-94.

Sen, Amartya (1990), "Gender and cooperative conflicts," In I. Tinker, ed. Persistent Inequalities: women and world development, Oxford, UK: Oxford University Press, pp. 123-49.

de Soto, Hernando (1989), The Other Path: the invisible revolution in the Third World, trans. June Abbott, New York: Harper and Row.

(2000), The Mystery of Capital: Why capitalism triumphs in the West and fails everywhere else, New York: Basic Books.

Stansell, Christine (1983), "The origins of the sweatshop: women and early industrialization in New York City," In M. Frisch and D. Walkowitz, eds. Working Class America, Urbana, IL: University of Illinois Press, pp. 78-103.

Tokman, Victor (1989), "Policies for a heterogeneous informal sector in Latin America," World Development, 17(7): 1067-76.

Unni, Jeemol (2001), "Wages and employment in unorganized sector: issues in wage policy," In A. Kundu and A.N. Sharma, eds. Informal Sector in India: perspectives and policies, New Delhi: Institute for Human Development (dist. By Manohar), pp. 124-41.

Weiss, Linda (1987), "Explaining the underground economy: state and social structure," The British Journal of Sociology 38(2): 216-34. 